\title{
EMOTIONAL INTELLIGENCE AND MANAGERIAL EFFECTIVENESS
}

\section{Saqib Anwar Saddiqui, Muhammad Jawad, Munazza Naz, Ghulam Shabir Khan Niazi}

(1) Department of leadership and Management Studies, National Defence University, Islamabad, Pakistan (2) Department Economics, University of York, York, United Kingdom (3) Department of Mathematics, University of York, York, United Kingdom (4) Department of leadership and Management Studies, National Defence University, Islamabad, Pakistan

\section{Saqib Anwar Saddiqui}

Department of leadership and Management Studies, National Defence University, Islamabad, Pakistan. saqib.phd@gmail.com

Article info Paper category: Original scientific paper Received: 20.12.2017. Accepted: 27.3.2018. JEL classification: M12

Keywords Emotional Intelligence; Managerial Effectiveness; Service Sector; Pakistan 


\section{ABSTRACT}

Purpose. In this research we have tried to identify the impact of emotional intelligence on the managerial effectiveness.

Design. The domains of emotional intelligence identified by the dr. Daniel goleman namely self-awareness, self-regulation, social skill \& empathy have been tested to include in the listing of 16 managerial skills namely confidence in subordinates, communication and task assignment, networking, colleagues management, discipline, informal communication, management of market environment, conflict resolution, integrity and communication, client management \& competence, motivating, delegation, image building, welfare management, consultative, \& inspection and innovation - the scale developed by seeta gupta in 1996. Statistical package for the social science is used for analysis. Descriptive analysis is used to define the key aspects and sample formation. Two tailed pearson correlation was applied to check and test the relationship among the variables used in the research. Regression analysis was used to identify the significance, magnitude and direction of the variables

Findings and implications. We have concluded that all four traits of emotional intelligence have been found significant, therefore suggested to include them in the scale of managerial effectiveness. 


\section{INTRODUCTION}

A popular proverb "People leave managers, not organization" indicates that handling people is always a difficult task from a long time. With the increasing demand of luxurious life and fast pace of technology growth, people are more educated and want to be dealt and handled with nice and polite way. This approach has also created a bottleneck situation for the mangers and leaders to lead their staff and teams with the hawk-eye for accomplishing of the assignments and dealing with the people with more sophisticated manner keep them motivated and retain the talent.

The impact of globalization has increased the competition in the business environment. The organizations require a team of managers to run the day to day operations. Identifying the team's abilities and capacity, build them into synergy, and become the consistently high-performing team is the need of today's business world. Today, in 21 century, the business organizations have been transformed into a complex structured with vigorous and increasingly erratic employees and customers. This has enforced the managers to think seriously for handling and dealing with such organisms and to convert the conventional structure with lively, mutually supporting, interactive and creative environment. To gain and maintain the competitive advantage in the market and industry, organizations need to prepare their employees to adapt and adjust in the changing environments, both externally and internally (Prati, Douglas, Ferris, Ammeter, \& Buckley, 2003).

Although, the literature has significant evidences that have linked the emotional intelligence with the trait ofleadership effectiveness, butverylittle material have been found which directly deals with the managerial effectiveness. The researchers have linked and tested the relationship between emotional intelligence and transformational leadership style, (Barling, Slater, \& Kelloway, 2000; Gardner \& Stough, 2002; Sivanathan \& Fekken, 2002). 'Transformational leaders' are said as those managers / executives who creates a vision, transform this vision into mission, build promising approach and attitude among subordinates towards the vision and create a challenging environment within the workplace. On the other hand, 'transactional leaders' are considered as typical managers who wish to and maintain the conventional state of ordering, commanding and power. They are more work concentrated and focus the traditional management practices by getting the work done on time and within the resources. Such managers usually keep the track of regular and ongoing activities and tasks and keep relating the job performance with incentives and rewards.

It is observed and believed that transformational leaders are more capable to take-up and handle the strategic matters of the organization and are able to develop commitment in employees in long run, such leaders are considered and are more likely to provide a broader vision and take an organization forward (Rosete \& Ciarrochi, 2005). 


\subsection{Emotions}

"Emotion" is the generic term used in the field of psychology, philosophy, and their many subsets, for subjective that refers to the "conscious experience". It describes the psycho-physiological expressions, biological reactions, and mental states in a human being.. Emotions are not limited to human beings only, they are also produced in other beings and creatures such as animal and birds (Mayer \& Salovey, 1997).

\subsection{Intelligence}

David Wechsler, who is well known due to his invention in developing the intelligence test scales, he has concluded that total intelligence cannot be measured until psychological tests are included to measures some of the "non-intellective factors." During the same era an Ohio State's investigation stated that leaders who can, and are good in establishing and maintaining mutual trust, respect, warmth and rapport in their teams are prove to be more effective than those who were merely brilliant, but cold and calculating strategists.

Intelligence is the function of cognitive part of human mind that pertains the abilities of the, "power to combine and separate", "concepts to judge and to reasons", and to "engage in abstract thought" (Mayer \& Salovey, 1997).

Intelligence $=\mathrm{f}$ (cognitive sphere of $\mathrm{mind})$

\subsection{Emotional intelligence}

Emotional Intelligence (EI) is defined, and is considered, as a capability of an individual to recognize and identify emotions, create and retrieve emotions and so help in attaining the state of contemplation (Mayer \& Salovey, 1997).

Goleman (1995) defines Emotional Intelligence as an aptitude of an individual to be familiar with his or her own feelings in term of emotions, strengths, weaknesses, needs,goals, drives and values, and to sought the same in others people working around him /her, to keep them motivated and maintaining healthier relationships with them. Thus, Emotional Intelligence is an assortment of non-cognitive capabilities, competencies, and skills that empower the individual to succeed in handling and deal with the environmental demands and pressures. IQ is not the final or even the most important predictor of successful job performance.

\subsection{Managerial effectiveness}

Stephen R. Covey defines effectiveness as those activities of an individual that incur the positive changes in tasks and relationships that benefit him/her in a long- 
term for the better results. Such activities form the habits of an individual that reflects the person's character. These habits enables the individual to perform effectively and consistently to solve the problems, to become an opportunist, work and learn continuously and gain the ladder of growth (Covey, 1989).

In modern era although the term or the factor of 'Managerial Effectiveness' has been molded into the 'Leadership Effectiveness' however, the previous researches have significant evidences that support the area of "Managerial Effectiveness" for the accomplishment of the better job done through staff and subordinates. The study on the factors of managerial effectiveness varies widely from organization to organization and from job to job and hence the criteria of effectiveness needs to be carefully and objectively defined (Sy, Tram, \& O'Hara, 2006). Mintzberg (1973) suggested that managers' jobs are remarkably similar and that the work of all managers can be usually described by common set of behaviors or roles. He stated that all managerial jobs can be defined in terms of ten roles: interpersonal (three), informational (three) and decisional (four). According to this approach, managers are effective in different ways at different times depending on the combination of different roles at each level.

Therefore, either it remains the word "Leadership" or "Managerial" the way to handle the "people" and "tasks" is the main focus for this research through the characteristic of "Emotional Intelligence". Therefore, this research has not been restricted to any specific sector, rather it has been diversified on the overall traits indentified for the managerial position in the organizations.

Gladson Nwokah and Augustine I. Ahiauzu (Nwokah \& Ahiauzu, 2009) tested the Goleman's (2001) four domains of emotional intelligence namely Self-awareness, Self - management (Self-regulation), Social -awareness (Empathy) and Relationship Management (Social skill) as predictor variables, the same has been adopted in this research to see the impact on the scale of managerial effectiveness developed by Seeta Gupta in her research Managerial Effectiveness (Gupta, Jan 1996).

\section{LITERATURE REVIEW}

\subsection{Brief history of Emotional intelligence}

In 1920 almost 90 years back, Thorndike (Thorndike, 1920) proposed the construct of social intelligence, he presented the theory of intelligence in which he organized the intelligence under 3 dimensions i.e. "mechanical intelligence", "abstract intelligence", and "social intelligence". The mechanical intelligence of an individual is the level of the ability and capacity to manage things and processes. The ability of an individual to manage and understand the ideas and symbols is categorized under the abstract intelligence; whereas the social intelligence refers to understanding and managing the people i.e. interpersonal situations. 
Thorndike's (Thorndike, 1920) classification of intelligence prompted and provided a roadmap for the expansion in the field of intelligence framework. However major emphasis was remained in the area and fields of mechanical and abstract intelligence during that era. Although some psychologists worked on the measurements and development of social intelligence and tried to explore the spectrum of the field but were remained under the criticism. Thorndike, himself (Thorndike \& Stein, 1937) expressed his doubt on the verbally derived instrument could measure social intelligence.

In 1983 Gardner presented the theory of multiple intelligences in which he explore the 2 dimensions of intelligence i.e. "interpersonal" and "intrapersonal" intelligence. The interpersonal theory deals with the philosophy of understanding other people; whereas, intrapersonal deals with understanding oneself.

Cantor and Kihlstrom in 1989 argued and suggested that social intelligence plays the major role in developing the cognitive aspects of personality in an individual. Schneider, Ackerman, and Kanfer in 1996 further elaborated the perspective and suggested that social intelligence directs and builds the social competence.

In 1997 Mayer and Salovey presented and published their analysis on the theories of social intelligence and supported the arguments of Schneider and others on the social intelligence as a global construct. Along with this, they presented the concept that, the group of abilities in an individual is different from the traditional dimensions of intelligence and are covered under the umbrella of 'Emotional Intelligence'. The conceptual framework of emotional abilities given by them consisted of 4 l levels hierarchy which includes the ability to perceive, appraise, and express emotion, an ability to use emotions to facilitate cognition, the ability to understand and analyze emotions, and the ability to regulate emotions to facilitate emotional and cognitive growth (Mayer \& Salovey, 1997).

\subsection{Emotional intelligence domains}

Emotional intelligence has relatively a young age as a variable of interest in organizational research. Researchers have examined the impact of emotional intelligence on transformational leadership, the attributes of leaders, and leadership in self-managing teams. (Jordan \& Troth, 2011)

\subsection{Transformational leaders}

Transformational leaders are called to be managers /executives that focuses to create a vision, build the intellectual stimulation, encourage, advocates and promote the productive and new ideas of staff, inspire motivation, trasmits optimism, build commitment amongst subordinates and provides the sence of direction within the workplace (Mandell \& Pherwani, 2003; Rosete \& Ciarrochi, 2005). The key characteristic of Transformational 
Leader is the focus on "Learning \& Knowing". The theory on transformational leadership is based on 4 , characteristics:

- Inspirational Motivation

- Intellectual Stimulation

- Idealized Influence

- Individualized Consideration

\subsection{Transactional leaders}

Transactional leaders are seems to be like conventional managers who expects more productivity form individual in return to give rewards. Their center of attention remains in providing the necessary resources to the employees needed to accomplish theirjob timely and linking their job performance to rewards.

Transactional Leaders are more focused towards tasks completion rather than individual interests and get the work done within the available resources. These leaders are change resistant and work under the defined rules, discouraging the innovation. They use predetermine criteria to monitor performance and believe in making all the decisions by themselves and expecting employees to simply follow the rules and instructions (Rosete \& Ciarrochi, 2005)

Transformational leaders are believed to be more diversified executives who are able to deal with strategic matters more efficiently and can build commitment in employees. Organizations are more likely to move forward and upward under the leadership of these executives. (Rosete \& Ciarrochi, 2005). The literature of Emotional Intelligence have been focused in perspective of transformational leadership and argued its contribution to effective leadership. (Jordan \& Troth, 2011).

Literature has provided the evidence that Emotional Intelligence has been referred to the traits of a human which includes 'motivation', 'empathy', 'sociability', 'warmth', and 'optimism' (Rosete \& Ciarrochi, 2005). Rosete and others have sorted out the EI approaches into 2 broad categories:

(1) Ability models and

(2) Mixed models.

Ability models describes and explains the Emotional Intelligence in the perspective of cognitive intelligence as depicted by Mayer and Salovey (i.e. intelligent quotient (IQ). On the other hand, mixed models of Emotional Intelligence assimilate both non-cognitive models as of Bar-On, 1997 and competency-based models as by Goleman, 1995 (Rosete \& Ciarrochi, 2005).

It has been reviewed form last 6 decades researches that researchers have used the the emotional construct to check and state the relationship between positive moods' and 'charismatic leadership', 'emotional management' and 'transformational leadership', 'emotional expression' and 'leader member exchange', 'leader's 
emotional displays' and 'followership behavior' etc . (Jordan \& Troth, 2011; John D. Mayer, Salovey, \& Caruso, 2004)

The paradigm of emotional intelligence given by Mayer and Salovey (1997) indicates 4 inter-related emotion processing abilities: (i) 'the perception', (ii) 'assimilation', (iii) 'understanding own and others emotions' and (iv) 'management of own and others emotions'.

In 2005 Ashkanasy and Daus provided the framework on EI based on 3 pillars whose foundations were linked with the Mayer and Salovey (1997) model of emotional intelligence. They materialized the emotional intelligence as a skill that should be measured as conventional intelligence tests with an "ability test". Other researchers agree with the idea and construct of Mayer and Salovey (1997), but argue that this ability can be measured through a "self report test". Finally, some researchers define emotional intelligence as a type of 'personality variable' (Jordan \& Troth, 2011).

Jordan et al. (2002) have examined and commented about the practical abilities of the emotional intelligent employees that they use and show in the workplace. According to them effective employees need to be aware and manage of their own emotions and the emotions of others in the workplace. Jordan and Lawrence (2009) while their business focused research, adopted a four dimension definition of individual emotional intelligence that replicate the generally accepted Mayer and Salovey (1997) model of emotional intelligence. This model comprises 4 constructs:

(1) 'Awareness of own emotion';

(2) 'Management of own emotion';

(3) 'Awareness of others emotion'; and

(4) 'Management of others emotion'.

Deniel Goleman reviewed his original model of emotional intelligence developed in 1995 in 1998. He sorted 25 social and emotional competencies that are most strongly predictor of superior performance in many occupations. Goleman organized these competencies into the five dimensions namely "self-awareness", "selfregulation", "self-motivation", "social awareness", and "social skills".

Goleman (1995) defines, emotional intelligence "is the capacity for recognizing our own feelings and those of others, for motivating ourselves, and for managing emotions well in ourselves and in our relationships." After the emergence of this periodical, many other researchers, writers and HR specialists have contributed enormously on the topic of Emotional Intelligence. Many definitions of Emotional Intelligence came into existance such as: "The ability to perceive and express emotion, assimilate emotion in thought, understand and reason with emotion, and regulate emotion in the self and others" (J. D Mayer, Salovey, \& Caruso, 2000). Cherniss and Adlet (G. Cherniss \& Adlet, 2000) have defined "emotional intelligence" as: "the ability to accurately identify and understand one's own emotional exactions and 
those of others." It has also been indicated by some authors, that emotional intelligence "also involves the ability to regulate one's emotions, to use them to make good decisions and to act effectively." They emphasized that emotional intelligence is the foundation for personal traits and characteristics such as knowledge of personal strengths and weaknesses, realistic self-confidence, personal integrity, selfmotivation, resilience in times of change or adversity, perseverance, and the skill for getting along well with others.

\subsection{Managerial effectiveness}

An organization needs effective and skilled executives to facilitate corporate success in the long run. Effectiveness of executives plays a vital role for the success of an organization in the contemporary business dome. Organizations need competent and SMART working managers to be able to achieve their objectives efficiently and effectively. The executives are employed for their skills and expertise to maximize the profitability of the organization. They induce a vital role in developing and executing of organization operations and create an affective function for the implementation of strategies and policies (Yang, Zhang, \& Tsui, 2010). In this context, "managerial effectiveness" is an important factor that enables effectual operations and delivery of complex initiatives (Bamel, Rangnekar, \& Rastogi, 2011).

According to Drucker (1967) managers are vital and the life giving elements in every business, and without them the resources cannot be converted into high production. A key function of managers is to determine what has to be done and how it is to be done.

Aggregation of employees' performance represents the organizational performance which places stress on the efficient use of resources and accomplishment of desirable outcomes. With increased dependency of business on information technology, managers are required to sort out new ways to facilitate organizational production and sustainable self-growth. The role is continually changing and becoming challenging with the increasing organizational complicated structures, globalization, the accelerated product life cycle, growing complexity of relationship with stakeholders, scarcity of the resources, and intense competition. Indeed, there has been the debate over how to assess executive managerial effectiveness, which provides a pathway for utilizing resources efficiently (Bamel, et al., 2011).

An effective manager is the one who knows and is aware from all kinds of behavior and actions which directs and lead towards organizational results and who then chooses to engage in those apposite to the environment, the particular managerial job, the situation, and his own personal preferences. Mintzberg (1973) suggested that manager's jobs are similar and the work done by the managers regardless of any industry can be described by the common set of behaviors and roles. He defined the manager's job in terms of ten roles: interpersonal (three), informational (three) and 
decisional (four). According to this approach, managers are effective in different ways at different times depending on the combination of different roles at each level.

Balaraman (1989) defined managerial effectiveness in behavioral terms which evaluated managers on selected job oriented criteria such as communication, cost awareness, delegation of work, labor relation, planning and scheduling, securing interdepartmental cooperation, training subordinates and utilization of capacity. Das (Das, 1987) recognized the distinctiveness of competent and capable branch managers as - setting an example by personal qualities and characteristics, grip on job knowledge and business intelligence and human-management ability. Misumi and Peterson in 1985 (J. Misumi \& Peterson, 1985; Jyuji Misumi, 1989) and 1989 defined the ideal manager in Japan as the one who leads the group towards goal accomplishment and safeguard its social stability in terms of both performance and maintenance.

According to Nwachuku (1989), an appropriate skill mix appears necessary in order to meet the instability in organizational demand. At lower levels of management (entry levels) technical skill is most important; at middle management level process skills (directing, coordinating, planning and controlling) are most essential; and at senior level conceptual skill is most relevant.

The model of managerial Effectiveness proposed by Campbell and others in 1970 covered the three main areas of an organization as a component of the model i.e. Person-Process-Product. The 'Person' in the model refers to the individual /manager's characteristics traits and abilities, 'Process' is the managers on the job activities and behavior, while 'Product' refers to the organizational results such as profit maximization and productivity. (Morse \& Wagner, 1978)

Morse and Wagner (Morse \& Wagner, 1978) developed an instrument to evaluate the performance and activities that account for similarities and differences among manager's jobs. They worked out the 6 factors instrument for an effective manager, i.e.

Factor I: $\quad$ Managing the Organization's environment and its resources

Factor II: Organizing and coordination

Factor III: Information handling

Factor IV: $\quad$ Providingforgrowth and development

Factor V: Motivating and conflict handling

Factor VI: $\quad$ Strategic problem solving

According to Morse and Wagner the work of all managers may be usefully described by the behavior and activities incorporated in the instrument, but it may be expected that different managers in different managerial jobs will place more or less attention on specific behavior associated with particular roles to perform effectively. For example, top-level and middle-level managers might probably be more 
concerned with the activities associated with "controlling the organization's environment and its resources" than low-level managers. Similarly, many managerial position requires working through and with people in the organization, and might have to attend to "motivating and conflict handling" activities. Concerning specific situational variables, managers facing a temporary crisis may give extra attention to activities involving "strategic problem solving" and less attention to activities involving, say, "providing for growth and development" until the crisis is resolved. (Morse \& Wagner, 1978; Page, Wilson, \& Meyer, 1999).

Thus, if the managers are to be effective, they categorized with the roles they engage in within the contingencies of the situation. Finally, it must be recognized that the manager himself is an important variable to consider in this approach to managerial effectiveness. Based on differences in personality predispositions, managerial style, skills, and abilities, managers may choose to emphasize particular roles and pay less attention to others. (Morse \& Wagner, 1978)

In 1996 Seeta Gupta developed the scale for Managerial Effectiveness in which she identified 19 dimensions from a literature review of behaviors and characteristics of the managers in India, which were further reduced to following sixteen.

F-I: Confidence in subordinates

F-IX: Integrity and Communication

F-II: Communication and task assignment F-X: Client Management \& Competence

F-III: Networking

F-XI: Motivating

F-IV: Colleagues management

F-XII: Delegation

F-V: Discipline

F-XIII: Image building

F-VI: Informal communication

F-XIV: Welfare management

F-VII: Management of market environment

F-XV: Consultative

F-VIII: Conflict Resolution

F-XVI: Innovation and inspiration

The scale appeared to be a useful instrument for appraising and evaluating the effectiveness of managers who were in managerial roles. Conceptually, the scale's items supported the definition of managerial effectiveness as the "Ability of a manager to carry out the activities required of his position while achieving the results both current and in terms of developing further potential". (Gupta, Jan 1996)

\subsection{Self-Awareness}

It is the capability of an individual to identify or recognize a feeling as it occurs. It describes the aptitude of a person who has an accurate understanding of his /her strengths and weaknesses. Being fully aware of what one feels in a moment and using that feeling guide him /herself to behave or respond. Self-Awareness is associated 
with the individual competencies as "emotional self-awareness", "accurate self-assessment" and "self-confidence" (Nwokah \& Ahiauzu, 2009).

The feature of self-awareness is associated with internal desire and anxiety control. If one get angry and get anxious easily, it is possible that others may infer this as a lack of self-awareness and may draw conclusions about as how he /she handle and behave in difficult and challenging circumstances. If one does not understand his /her own feelings, he /she won't be good at controlling others - or reading other people.

The skills and the features of a self-aware person are:

(a) Be willing to examine how one makes his/her own evaluations.

(b) Recognize negative thinking, anger and mood swings.

(c) Practice tuning into own senses $\left(\right.$ all $\left._{5}\right)$

(d) Make an effort to learn one's own intentions.

(e) Pay attention to own behaviors

\subsection{Self-Management}

Self-Management or Self-Regulation is the capability to control or regulate the feelings /emotions to keep them in balance - especially negatives ones. It is the capacity of a person to keep in touch what he /she feels and keep the balance between the good and bad feeling. It is the learning to be a balanced in daily life. Gardner (1983) suggested the Self-Awareness \& Self-Management domains of EI as "Intrapersonal Intelligence" (Nwokah \& Ahiauzu, 2009).

If someone is not good in self-management trait and is unable to control the feelings as it occurs, it is possible that he /she may get controlled by the feelings particularly powerful and intensive ones like anger, frustration or panic (Nwokah \& Ahiauzu, 2009).

The skills, competencies and the features that are required to be Self-Managed includes:

(a) Learn how to use self-talk as a tool and a skill

(b) Avoid negative thinking.

(c) Learn relaxation skills

(d) Develop and use a sense of humor

(e) Self-Control

(f) Transparency

(g) Adaptability 
(h) Achievement

(i) Initiative

(j) Optimism

\subsection{Social Awareness}

Social awareness or Empathy is counted towards the most influential and compelling of emotionally intelligent management practices. It the aptitude to know and read how others are feeling, have the approach according to their viewpoint - without letting yourself to be controlled by someone else's feelings. It is being able to feel as others feel. Over two decades ago, Rosenthal (1977) and his colleagues at Harvard acclaimed that people who are most excellent in recognizing others emotions are more successful in their work as well as in their social lives (Cherniss, 2000).

The skills desired for being Socially Aware includes:

(a) Learn to use sensitivity

(b) Become aware of own defenses

(c) Take time to tune into the emotional background of own environment.

(d) Practice matching communication with others:

(i) Demonstration with a student volunteer re: empathic responses.

(ii) Discussion of demonstration.

\subsection{Relationship Management}

It is the learning to interact in a healthy manner with others. Developing long lasting, positive relationships and using the other Emotional Intelligence dimensions to influence, lead, negotiate, collaborate and network. Gardner (1983) suggested the Social-Awareness \& Relationship Management domains of Emotional Intelligence as "Inter-personal

Intelligence" (Nwokah \& Ahiauzu, 2009).

(a) Pay attention to the details of own relationships.

(b) Maintain own emotional perspective.

(c) Anticipate own moods in situations that will be encountered.

(d) Learn to be an active listener. 


\section{RESEARCH METHODOLOGY}

\subsection{Introduction}

This research involves the quantitative research methodology and was conducted to analyze the influence of Emotional Intelligence on Managerial Effectiveness through questionnaire adopted from two difference researches.

\subsection{Research questions}

This research was envisioned to know the answers of following questions:-

- Does Self-awareness improve the efficiency of a Manager?

- Does Self-management contribute positively to the effectiveness of a Manager?

- Is Social awareness is necessary for Managerial Effectiveness?

- Does Relationship management have any impact on Managerial Effectiveness?

- Do Emotional Intelligence can be included in Managerial Effectiveness Scale?

\subsection{Research variables and hypothesis: Independent variables}

\subsubsection{Self-Awareness (SeA)}

"Self-Awareness" is the trait of Emotional Intelligence which briefs about the person knowledge about him /herself. It is the ability to identify or recognize a feeling as it occurs. It describes the aptitude of a person who has an accurate understanding of his /her strengths and weaknesses. It has been used in this research as an independent variable to see the relationship on the dependent variable i.e. Managerial Effectiveness.

It will provide that if the results are positive it will indicate that it is needed in a manager for handling people and tasks effectively.

So, the Hypothesis developed is:-

H1: Self-awareness leads to Managerial Effectiveness

Equation: $\quad M E=A+B(\operatorname{Se} A)$

\subsubsection{Self-Management (SeM)}

Self-Management is the ability to control or regulate the feelings /emotions to keep them in balance - especially negatives ones. It is the capacity of a person to keep in touch what he /she feels and keep the balance between the good and bad feeling. It is the learning to be a balanced in daily life. In this research it is used as independent 
variable to see the relationship on the dependent variable i.e. Managerial Effectiveness.

It will prove that if the results are positive it will indicate that it is needed in a manager for handling people and tasks effectively.

So, the Hypothesis developed is:-

$\mathrm{H}_{2}$ :Self-management contributes positively to Managerial Effectiveness

Equation: $M E=A+B(S e M)$

\subsubsection{Social-Awareness (SoA)}

Social Awareness is the capability to know and interpret how others are feeling, taking, their perspective into substance and relate to others - without allowing yourself to be hijacked by someone else's feelings. It is being able to feel as others feel. In this research it is used as independent variable to see the relationship on the dependent variable i.e. Managerial Effectiveness.

If the results are positive it will indicate that it is needed in a manager for handling people and tasks effectively.

So, the Hypothesis developed is:-

H3:Social awareness has a positive influence on Managerial Effectiveness Equation: $M E=A+B\left(S_{0} A\right)$

\subsubsection{Relationship Management (ReM)}

Relationship Management is also a characteristic of Emotional Intelligence. It is the learning to interact in a healthy manner with others. Building enduring, positive relationships and using the other Emotional Intelligence dimensions to persuade, lead, negotiate, collaborate and network (Ghiabi \& Besharat, 2011). In this research it is used as independent variable to see the relationship over the dependent variable i.e. Managerial Effectiveness.

If the results are positive it will indicate that it is needed in a manager for handling people and tasks effectively.

So, the Hypothesis developed is:-

$\mathrm{H}_{4}$ : $\quad$ Relationship management leads to Managerial Effectiveness

Equation: $M E \quad=A+B($ ReM $)$

\subsection{Dependent variable}

\subsubsection{Managerial Effectiveness (ME)}

Managerial Effectiveness can be defined as a process of change due to influence and actions of a manager in the hole process of the business operations which directs 
and leads towards improved organizational results and who then chooses to engage in those opposite to the environment. In this research it is used as dependent variable to see the relationship with 4 , domains of Emotional Intelligence

If the results are positive it will indicate that Emotional Intelligence is necessary for handling people and tasks effectively.

So, the Hypothesis developed is:-

$\mathrm{H}_{5}$ : Emotional Intelligence is considered as a scale of Managerial Effectiveness

Equation: $M E \quad=A+B(E I)$

\subsubsection{Research type \& data collection tool / questionnaire}

A survey research was carried out to collect the primary data and test our conceptual model from 357 respondents working at some managerial/ supervisory level in service industry. The tested questionnaire of Likert sacle from 1 to 5 was adopted form previously held researches on the variables used in this research. The Part-I of the questionnaire contains the 45 questions related to 'managerial effectiveness' adopted form the research of Seeta Gupta an Indian author from her research "Managerial Effectiveness: Conceptual Framework and Scale Development" (Gupta, Jan 1996). Part-II of the questionnaire contains 20 questions in context to "Emotional Intelligence' was adopted form the research of Gladson, Nwokah, \& Ahiauzu, titled "Emotional intelligence and marketing effectiveness" (Nwokah \& Ahiauzu, 2009)

\subsection{Population}

The target population of the current study was the employees of service industry working at supervisory or managerial position. Population comprised of elements using corporate sectors of Rawalpindi /Islamabad, Lahore \& Karachi. The corporate companies included in this research were Ufone, Warid, Mobilink, Telenor, Faysal Bank Limited (FBL), Habib Bank Limited (HBL), United Bank Limited (UBL), Allied Bank Limited (ABL), Bank Alfalah Limited (BAF), Standard Chartered Bank (SCB). The estimated population of managers in these organizations was calculated to near about 5000 .

\subsection{Sample}

Random sample of 357 managers was selected as per the Table 1 . of Uma Sekaran Book page 295 (Sekaran \& Bougie, 1984) from the managers working in 10 selected organizations for the estimated population of 5000 . 
The questionnaires were floated as per bifurcation presented in Table $1 .$.

Table 1.: Random sample

\begin{tabular}{|l|r|r|}
\hline \multicolumn{1}{|c|}{ Organization } & Qty distributed & Qty returned \\
\hline Faysal Bank Limited (ISB, RWP, LHR, KHI) & 80 & 55 \\
Allied Bank Limited(ISB, RWP, LHR) & 50 & 36 \\
Habib Bank Limited (ISB, RWP) & 4.0 & 18 \\
Standard Chartered Bank (RWP, ISB) & 4.0 & 10 \\
United Bank Limited (RWP, ISB, LHR) & 4.0 & 28 \\
Bank Alfalah Limited (RWP, ISB, LHR, KHI) & 4.0 & 13 \\
Telenor & 20 & 3 \\
Ufone & 20 & 8 \\
Warid Tel & 20 & 5 \\
Mobilink & 20 & 2 \\
Others & 30 & 13 \\
Total & 4.0 & 191 \\
\hline
\end{tabular}

Source: Authors.

\subsection{Data analysis technique}

Once the data was collected statistical tools and techniques were required to analyze and examine information, as this is quantitative in nature.

SPSS v.16.o for Windows was used to apply the related statistical tools. Two tailed Pearson correlation was applied to check and test the relationship among the variables used in the research. Correlation analysis helped in determining the degree and form of relationship between Self-Awareness (SeA), Self-Management (SeM), Social-Awareness (SoA) \& Relationship Management (ReM) with dependent variable Managerial Effectiveness (ME).

Regression analysis was used to identify the significance of Self-Awareness (SeA) \& Managerial Effectiveness (ME), Self-Management (SeM) \& Managerial Effectiveness (ME), Social-Awareness (SoA) \& Managerial Effectiveness (ME), Relationship Management (ReM) \& Managerial Effectiveness (ME) and over all SeA + $\mathrm{SoA}+\mathrm{SeM}+\mathrm{ReM} \& \mathrm{ME}$.

\section{RESULTS}

\subsection{Descriptive analysis}

For the estimated population for this research the sample was drawn to 357 . However, 4,00 questionnaires were floated to supervisory/ manager level staff of 10 companies in the area of Islamabad, Rawalpindi, Lahore \& Karachi, but total of 191 
was returned. The overall response rate in this research remained to $53 \cdot 5^{\%}$. The reason for such low response rate was the difficulty of the questionnaire as it was adopted from previously held researches and secondly the busy and hectic office time routine of the respondents as it was to be collected for supervisory level staff of banks and mobile operators company. Maximum of the respondents were given the personal assistance through self-administered and acquaintance's assistance. Response from male respondents was $66.5 \%$ and female was $33.5 \%$.

The maximum respondents were found from the age group of, 3o-35 \& 36-40 which were $73.30 \%$ of the total respondents. Therefore the results of our demographic characteristics were not normally distributed. It can be controlled if some more time is given to the respondents and continuous follow-up is kept.

\subsection{Reliability analysis}

Reliability analysis through Cronbach Alpha was conducted to test and determine the inter correlations among the items of the variables of our study.

The reliability analysis for the complete model of 65 items is 0.914 , which shows that the framework of our study is significantly reliable which can be used to apply further statistical tests to generate generalize results.

Table 2.: Reliability analysis of complete model

\begin{tabular}{|c|c|}
\hline Cronbach's Alpha & $\mathbf{N}$ \\
\hline $\begin{array}{l}.914 \\
\text { Table 2(a) } \\
\text { Reliability Analysis of Managerial Effectiveness }\end{array}$ & 65 \\
\hline $\begin{array}{l}.903 \\
\text { Table } 2(b)\end{array}$ & 45 \\
\hline $\begin{array}{l}\text { Reliability analysis of Emotional Intelligence } \\
.711\end{array}$ & 20 \\
\hline
\end{tabular}

Source: Authors.

\subsection{Descriptive analysis}

Following table shows the values of descriptive statistics with skewness and kurtosis for $\mathrm{N}=191$. Skewness is the numerical measure of shape that tells the amount and direction of skew (departure from horizontal symmetry), whereas Kurtosis tells how tall and sharp the central peak is, relative to a standard bell curve. 
Table 3.: Descriptive statistics

\begin{tabular}{|l|r|r|r|r|r|r|}
\hline & Min. & Max. & Mean & $\begin{array}{c}\text { Std. } \\
\text { deviation }\end{array}$ & Skewness & \\
\hline & & & & & Stat & Std. error \\
Managerial & 1.7778 & 4.7111 & 3.7996 & .4376 & -.435 & .176 \\
$\begin{array}{l}\text { Effectiveness } \\
\begin{array}{l}\text { Self- } \\
\text { Awareness }\end{array}\end{array}$ & 1.4000 & 5.0000 & 3.8816 & .4439 & -.136 & .176 \\
$\begin{array}{l}\text { Self- } \\
\text { Management }\end{array}$ & 2.0000 & 4.8333 & 3.6849 & $.485^{2}$ & -.437 & .176 \\
$\begin{array}{l}\text { Social- } \\
\text { Awareness }\end{array}$ & 2.0000 & 5.0000 & 4.0392 & $.495^{8}$ & -.772 & .176 \\
$\begin{array}{l}\text { Relationship } \\
\text { Management }\end{array}$ & 1.8000 & 5.0000 & 3.8324 & .4794 & -.877 & .176 \\
\hline
\end{tabular}

Source: Authors.

Bulmer, M. G., Principles of Statistics (Dover, 1979)-suggests this rule of thumb: "

- If skewness is less than -1 or greater than +1 , the distribution is highly skewed.

- If skewness is between -1 and $-1 / 2$ or between $+1 / 2$ and +1 , the distribution is moderately skewed.

- If skewness is between $-1 / 2$ and $+1 / 2$, the distribution is approximately symmetric."

Therefore, for this research the skewness of Managerial Effectiveness (-0.435) lies in the category of approximately symmetric, skewness of Self-Awareness (-1.136) lies in highly skewed, skewness of Self-Management (-0.437) lies in approximately symmetric, skewness of Social-Awareness (-0.772) moderately skewed and skewness of Relationship Management (-0.877) lies in moderately skewed. Since all the variables are negatively skewed which indicate that the left tail is longer for all the variables.

When the distribution is symmetric, we need to analyze the central peak for its height and sharpness; this analysis is measured by a number called Kurtosis. Higher values indicate the higher and sharper peak, lower values indicate less distinct peak. Higher kurtosis means more of the variability is due to a few extreme differences from the mean, rather than a lot of modest differences from the mean. The values of Kurtosis for different distributions are as follows:

- "A normal distribution has kurtosis exactly 3 (excess kurtosis exactly o). Any distribution with kurtosis $\cong 3$ (excess $\cong 0$ ) is called mesokurtic.

- A distribution with kurtosis $<3$ (excess kurtosis $<0$ ) is called platykurtic. Compared to a normal distribution, its central peak is lower and broader, and its tails are shorter and thinner.

- A distribution with kurtosis $>3$ (excess kurtosis >0) is called leptokurtic. Compared to a normal distribution, its central peak is higher and sharper, and its tails are longer and fatter. 
The smallest possible kurtosis is 1 (excess kurtosis -2), and the largest is infinity $(\infty) . "$

\subsection{Factor analysis}

Factor analysis is used to determine the characteristics and the behavior of the items / questions asked in the questionnaire whether they relate or not to the construct that is intended to be measured. Since the questionnaire adopted in our research was from multiple resources that's why we have applied exploratory factor analysis on our data. The results indicate that there is no problem of multi-collinearity and singularity in our data.

The KMO and Bartlett's test values lies between o and 1, which shows the Sampling Adequacy. In our data the value of Sampling Adequacy measures to 0.754 which is significant. Therefore factor analysis is appropriate for this data.

Table 4.: KMO and Bartlett's test

\begin{tabular}{|l|r|r|}
\hline Kaiser-Meyer-Olkin Measure of Sampling Adequacy & .754 \\
Bartlett's test of & Approx. Chi-Square & 1.065 \\
sphericity & Df & 2080 \\
& Sig. & .000 \\
\hline
\end{tabular}

Source: Authors.

\subsection{Correlation analysis}

Correlation analysis was carried out using Pearson correlations among all the variables. Pearson correlation indicates the relationship between two variables which could be either positive or negative i.e either in same direction or opposite direction (Jawad et al., 2018).

Since the Pearson Correlation of Managerial Effectiveness (ME) with SelfAwareness (SeA), Self-Management (SeM), Social-Awareness (SoA) \& Relationship Management ( $\mathrm{ReM}$ ) for $\mathrm{N}=191$ is $0.555,0.542,0.292$ \& 0.357 respectively which indicates that all Independent Variables have positive relationship /correlation with the dependent variable i.e. changes in SeA, SeM, SoA or ReM will bring change in ME in the same direction i.e. positive.

The Sig. (2_tailed) value of all correlation is $0.000<0.05$ it is concluded that the correlation between SeA, SeM, SoA, ReM \& ME is statistically significant. 
Table 5.: Correlation analysis

\begin{tabular}{|c|c|c|c|c|c|c|c|}
\hline & & ME & SeA & $\mathrm{SeM}$ & SoA & ReM & EI \\
\hline $\begin{array}{l}\text { Managerial } \\
\text { Effectiveness } \\
\text { (ME) }\end{array}$ & $\begin{array}{r}\begin{array}{r}\text { Pearson } \\
\text { correlation }\end{array} \\
\text { Sig. (2-tailed) }\end{array}$ & 1 & & & & & \\
\hline $\begin{array}{l}\text { Self Awareness } \\
\text { (SeA) }\end{array}$ & $\begin{array}{r}\text { Pearson } \\
\text { correlation } \\
\text { Sig. }(2 \text {-tailed) }\end{array}$ & $\begin{array}{l}.555^{* *} \\
.000\end{array}$ & 1 & & & & \\
\hline $\begin{array}{l}\text { Self Management } \\
\text { (SeM) }\end{array}$ & $\begin{array}{r}\text { Pearson } \\
\text { correlation } \\
\text { Sig. }(2 \text {-tailed })\end{array}$ & $\begin{array}{l}.542^{* * *} \\
.000\end{array}$ & $\begin{array}{l}.541^{* * *} \\
.000\end{array}$ & 1 & & & \\
\hline $\begin{array}{l}\text { Social Awareness } \\
\text { (SoA) }\end{array}$ & $\begin{array}{r}\text { Pearson } \\
\text { correlation } \\
\text { Sig. (2-tailed) }\end{array}$ & $\begin{array}{l}.292^{* * *} \\
.000\end{array}$ & $\begin{array}{l}.276^{* * *} \\
.000\end{array}$ & $\begin{array}{l}.263^{* * *} \\
.000\end{array}$ & 1 & & \\
\hline Relationship & & & & & & & \\
\hline $\begin{array}{l}\text { Management } \\
(\operatorname{ReM})\end{array}$ & $\begin{array}{r}\text { Pearson } \\
\text { correlation }\end{array}$ & $.357^{* *}$ & $.382^{* * *}$ & $.170^{*}$ & $.271^{* * *}$ & 1 & \\
\hline & Sig. (2-tailed) & .000 & .000 & .019 & .000 & & \\
\hline $\begin{array}{l}\text { Emotional } \\
\text { Intelligence }\end{array}$ & $\begin{array}{r}\text { Pearson } \\
\text { correlation }\end{array}$ & $.622^{* * *}$ & $\cdot 774^{* * *}$ & $.707^{* * *}$ & $.660^{* *}$ & $.65^{3 * *}$ & 1 \\
\hline & Sig. (2-tailed) & .000 & .000 & .000 & .000 & .000 & \\
\hline
\end{tabular}

Source: Authors.

**. Correlation is significant at the 0.01 level (2-tailed).

*. Correlation is significant at the 0.05 level (2-tailed).

\subsection{Regression analysis}

Regression Analysis is used to calculate and test the power of independent variable upon which it explains the dependent variable. In this research simple linear regression is used to test the hypothesis, because we needed to check the impact of one independent variable on the dependent variable in each hypothesis. The regression equation used is:

$$
\mathbf{Y}=\mathbf{a}+\mathbf{b}(\mathbf{X})
$$

Where a and b are regression coefficients which are used to measure of how independent variable predicts dependent variable. 


\subsection{Hypothesis 1}

Table 6 (a).: H1 - Model summary

\begin{tabular}{|c|r|r|r|r|}
\hline Model & R & R square & \multicolumn{1}{c|}{$\begin{array}{c}\text { Adjusted R } \\
\text { square }\end{array}$} & $\begin{array}{c}\text { Std. error of the } \\
\text { estimate }\end{array}$ \\
\hline & & & & \\
1 & $.555 \mathrm{a}$ & .308 & .304 & .3649732 \\
\hline
\end{tabular}

Source: Authors.

a. Predictors: (Constant), SeA

The Model Summary of independent variable Self-Awareness (SeA) \& dependent variable Managerial Effectiveness (ME) provides that there is positive linear relationship with $30.8 \%$ of variance.

Table 6 (b).: $\mathrm{H}_{1}$ - ANOVA table

\begin{tabular}{|r|r|r|r|r|r|r|}
\hline & Model & $\begin{array}{c}\text { Sum of } \\
\text { squares }\end{array}$ & df & \multicolumn{1}{c|}{$\begin{array}{c}\text { Mean } \\
\text { square }\end{array}$} & F & \multicolumn{1}{c|}{ Sig. } \\
\hline \multirow{3}{*}{1} & & & & & & \\
& Regression & 11.212 & 1 & 11.212 & 84.169 & .000 \\
& Residual & 25.176 & 189 & .133 & & \\
& Total & 36.388 & 190 & & & \\
\hline
\end{tabular}

Source: Authors.

a. Predictors: (Constant), SeA

The ANOVA table provides the regression analysis, predicting Managerial Effectiveness (ME) from Self-Awareness. The results for the selected variables indicates the significance of F-test at 95\% confidence interval. Since the Sig. value is . .०० so independent variable Self-Awareness explains, variation in dependent variable (Managerial Effectiveness) significantly.

Table 6 (c).: $\mathrm{H}_{\mathbf{l}}$ - Standardized \& unstandardized coefficients for ME

\begin{tabular}{|c|c|c|c|c|c|c|}
\hline & & $\begin{array}{l}\text { Unstandardized } \\
\text { coefficients }\end{array}$ & & $\begin{array}{c}\text { Standardized } \\
\text { coefficients }\end{array}$ & & \\
\hline \multirow{3}{*}{1} & Model & B & Std. error & Beta & $\mathrm{t}$ & Sig. \\
\hline & (Constant) & 1.676 & 233 & & 7.191 & .000 \\
\hline & SeA & .547 & .060 & .555 & 9.174 & .000 \\
\hline
\end{tabular}

Source: Authors 
The Coefficient of the test indicate that the t values associated with Self-Awareness is significant at the same level of F statistics. The regression equation will form the following shape:
$\mathrm{ME}=$
$1.676+0.547(\mathrm{SeA})$

Hence, we accept the $\mathrm{H}_{1}$ : Self-awareness leads to Managerial Effectiveness

\subsection{Hypothesis 2}

Table 7 (a).: $\mathrm{H}_{2}$ - Model summary

\begin{tabular}{|c|r|r|r|r|}
\hline Model & R & R square & \multicolumn{1}{c|}{$\begin{array}{c}\text { Adjusted R } \\
\text { square }\end{array}$} & $\begin{array}{c}\text { Std. error of the } \\
\text { estimate }\end{array}$ \\
\hline & & & & \\
1 & $.542 \mathrm{a}$ & .293 & .289 & .3688789 \\
\hline
\end{tabular}

Source: Authors.

a. Predictors: (Constant), SeM

The Model summary of independent variable Self-Management (SeM) \& dependent variable Managerial Effectiveness (ME) provides that there is positive linear relationship with $29.3 \%$ of variance.

Table 7 (b).: $\mathrm{H}_{2}$ - ANOVA table

\begin{tabular}{|c|c|c|c|c|c|c|}
\hline & Model & $\begin{array}{l}\text { Sum of } \\
\text { squares }\end{array}$ & df & $\begin{array}{l}\text { Mean } \\
\text { square }\end{array}$ & $\mathbf{F}$ & Sig. \\
\hline \multirow[t]{3}{*}{1} & Regression & 10.670 & 1 & 10.670 & $7^{8.41} \cdot 15$ & $.000 a$ \\
\hline & Residual & $25 \cdot 7^{18}$ & 189 & .136 & & \\
\hline & Total & 36.388 & 190 & & & \\
\hline
\end{tabular}

Source: Authors.

a. Predictors: (Constant), SeM

The above table provides the regression analysis, predicting Managerial Effectiveness (ME) from Self-Management. The results for the selected variables indicates the significance of F-test at 95\% confidence interval. Since the Sig. value is 0.000 so independent variable Self-Management explains, variation in dependent variable (Managerial Effectiveness) significantly. 
Table 7 (c).: $\mathrm{H}_{2}$ - Standardized \& unstandardized coefficients for ME

\begin{tabular}{|c|c|c|c|c|c|c|}
\hline & & $\begin{array}{c}\text { Unstandardized } \\
\text { coefficients }\end{array}$ & & $\begin{array}{c}\text { Standardized } \\
\text { coefficients }\end{array}$ & & \\
\hline \multirow{3}{*}{1} & Model & B & Std. error & Beta & $\mathrm{T}$ & Sig. \\
\hline & (Constant) & 2.000 & .205 & & $9 \cdot 75^{8}$ & .000 \\
\hline & SeM & .488 & .055 & .542 & 8.855 & .000 \\
\hline
\end{tabular}

Source: Authors.

The Coefficient of the test indicate that the $t$ values associated with Self-Management is significant at the same level of $\mathrm{F}$ statistics was. The regression eq will form the following shape:

$\mathrm{ME}=2.00+0.488(\mathrm{SeM})$

Hence, we accept the $\mathbf{H}_{2}$ : Self-management contributes positively to Managerial Effectiveness

\subsection{Hypothesis 3}

Table 8 (a).: H3 - Model summary

\begin{tabular}{|r|r|r|r|r|}
\hline Model & R & R square & \multicolumn{1}{c|}{$\begin{array}{c}\text { Adjusted R } \\
\text { square }\end{array}$} & $\begin{array}{c}\text { Std. error of the } \\
\text { estimate }\end{array}$ \\
\hline & & & & \\
1 & $.292 \mathrm{a}$ & .085 & .080 & .4196621 \\
\hline
\end{tabular}

Source: Authors.

Table 8 (b).: H3 - Model summary

\begin{tabular}{|l|r|r|r|r|}
\hline \multicolumn{1}{|c|}{ Model } & R & R square & \multicolumn{1}{c|}{$\begin{array}{c}\text { Adjusted R } \\
\text { square }\end{array}$} & $\begin{array}{c}\text { Std. error of the } \\
\text { estimate }\end{array}$ \\
\hline $1 \quad$ a & $.292^{2}$ & .085 & .080 & .4196621 \\
$\begin{array}{l}\text { a. Predictors: } \\
\text { (Constant), } \\
\text { SoAavg }\end{array}$ & & & & \\
\hline
\end{tabular}

Source: Authors.

The Model summary of independent variable Social-Awareness (SoA) \& dependent variable Managerial Effectiveness (ME) provides that there is positive linear relationship with $8.5 \%$ of variance. 
Table 8 (c).: H3 - ANOVA table

\begin{tabular}{|r|r|r|r|r|r|r|}
\hline & Model & $\begin{array}{c}\text { Sum of } \\
\text { squares }\end{array}$ & Df & $\begin{array}{c}\text { Mean } \\
\text { square }\end{array}$ & \multicolumn{1}{c|}{ F } & \multicolumn{1}{c|}{ Sig. } \\
\hline \multirow{3}{*}{1} & Regression & 3.102 & 1 & 3.102 & 17.611 & $.000 \mathrm{a}$ \\
& Residual & 33.286 & 189 & .176 & & \\
& Total & 36.388 & 190 & & & \\
\hline
\end{tabular}

Source: Authors.

a. Predictors: (Constant), SoAavg

The above table provides the regression analysis, predicting Managerial Effectiveness (ME) from Social-Awareness. The results for the selected variables indicates the significance of F-test at 95\% confidence interval. Since the Sig. value is 0.000 so independent variable Social-Awareness explains, variation in dependent variable (Managerial Effectiveness) significantly.

Table 8 (d).: H3 - Standardized \& unstandardized coefficients for ME

\begin{tabular}{|r|r|r|r|r|r|r|}
\hline & & $\begin{array}{c}\text { Unstandardized } \\
\text { coefficients }\end{array}$ & & \multicolumn{1}{c|}{$\begin{array}{c}\text { Standardized } \\
\text { coefficients }\end{array}$} & & \\
\hline \multirow{4}{*}{1} & Model & $\mathrm{B}$ & Std. error & Beta & $\mathrm{T}$ & Sig. \\
& (Constant) & 2.759 & .250 & & 11.04 .0 & .000 \\
& SoA & .258 & .061 & .292 & 4.197 & .000 \\
\hline
\end{tabular}

Source: Authors.

The Coefficient of the test indicate that the $t$ values associated with Self-Management is significant at the same level of F statistics. So, the regression eq will form the following shape:
$\mathrm{ME}=$
$2.759+0.25^{8}(\mathrm{SoA})$

Hence, we accept the H3: Social awareness has a positive influence on Managerial Effectiveness

\subsection{Hypothesis 4}

Table 9(a).: $\mathrm{H}_{4}$ - Model summary

\begin{tabular}{|c|c|c|c|c|}
\hline Model & $\mathbf{R}$ & R square & $\begin{array}{l}\text { Adjusted R } \\
\text { square }\end{array}$ & $\begin{array}{c}\text { Std. error of the } \\
\text { estimate }\end{array}$ \\
\hline 1 & $.357^{a}$ & .128 & .123 & $.4097^{8} 7^{3}$ \\
\hline
\end{tabular}

Source: Authors.

a. Predictors: (Constant), ReM 
The Model summary of independent variable Relationship Management (ReM) \& dependent variable Managerial Effectiveness (ME) provides that there is positive linear relationship with $12.8 \%$ of variance.

Table 9(b).: $\mathrm{H}_{4}$ - ANOVA table

\begin{tabular}{|r|r|r|r|r|r|r|}
\hline & Model & $\begin{array}{c}\text { Sum of } \\
\text { squares }\end{array}$ & \multicolumn{1}{c|}{ df } & \multicolumn{1}{c|}{$\begin{array}{c}\text { Mean } \\
\text { square }\end{array}$} & \multicolumn{1}{c|}{ F } & \multicolumn{1}{c|}{ Sig. } \\
\hline \multirow{2}{*}{1} & Regression & 4.650 & 1 & 4.650 & 27.689 & .000 \\
& Residual & 31.738 & 189 & .168 & & \\
& Total & 36.388 & 190 & & & \\
\hline
\end{tabular}

Source: Authors.

a. Predictors: (Constant), ReM

The above table provides the regression analysis, predicting Managerial Effectiveness (ME) from Relationship Management. The results for the selected variables indicates the significance of F-test at 95\% confidence interval. Since the Sig. value is 0.000 so independent variable Social-Awareness explains, variation in dependent variable (Managerial Effectiveness) significantly.

Table 9(c).: $\mathrm{H}_{4}$ - Standardized \& unstandardized coefficients for ME

\begin{tabular}{|r|r|r|r|r|r|r|}
\hline & & $\begin{array}{c}\text { Unstandardized } \\
\text { coefficients }\end{array}$ & & $\begin{array}{c}\text { Standardized } \\
\text { coefficients }\end{array}$ & & \\
\hline \multirow{4}{*}{1} & Model & B & Std. error & Beta & $\mathrm{T}$ & Sig. \\
& & & & & 10.645 & .000 \\
& (Constant) & 2.549 & .239 & .357 & 5.262 & .000 \\
\hline
\end{tabular}

Source: Authors.

The Coefficient of the test indicate that the t values associated with Relationship Management is significant at the same level of F statistics. So, the regression eq will form the following shape:

ME $\quad 2.549+0.326(\mathrm{ReM})$

Hence, we accept the $\mathbf{H}_{4}$ : Relationship management leads to Managerial Effectiveness 


\subsection{Hypothesis 5:}

Table 10(a).: $\mathrm{H}_{5}$ - Model summary

\begin{tabular}{|c|r|r|r|r|}
\hline Model & R & R square & \multicolumn{1}{c|}{$\begin{array}{c}\text { Adjusted R } \\
\text { square }\end{array}$} & $\begin{array}{l}\text { Std. error of the } \\
\text { estimate }\end{array}$ \\
\hline 1 & .622a & .387 & .384 & .3435460 \\
\hline
\end{tabular}

Source: Authors.

a. Predictors: (Constant), EI

The Model summary of complete Model of Emotional Intelligence \& dependent variable Managerial Effectiveness (ME) provides that there is positive linear relationship with $38.7 \%$ of variance.

Table 10(b).: $\mathrm{H}_{5}$ - ANOVA table

\begin{tabular}{|l|r|r|r|r|l|}
\hline \multicolumn{1}{|c|}{ Model } & \multicolumn{1}{|c|}{$\begin{array}{c}\text { Sum of } \\
\text { squares }\end{array}$} & Df & Mean square & \multicolumn{1}{c|}{ F } & \multicolumn{1}{c|}{ Sig. } \\
\hline 1Regression & 14.081 & 1 & 14.081 & 119.307 & $.000 \mathrm{a}$ \\
Residual & 22.307 & 189 & .118 & & \\
Total & 36.388 & 190 & & & \\
\hline
\end{tabular}

Source: Authors.

a. Predictors: (Constant), EI

The ANOVA table provides the regression analysis, predicting Managerial Effectiveness (ME) from Emotional Intelligence (EI). The results for the selected variables indicates the significance of F-test at 95\% confidence interval. Since the Sig. value is 0.000 so model of Emotional Intelligence explains, variation in dependent variable (Managerial Effectiveness) significantly.

Table 1o(c).: $\mathrm{H}_{5}$ - Standardized \& unstandardized coefficients for ME

\begin{tabular}{|r|r|r|r|r|r|r|}
\hline & & $\begin{array}{c}\text { Unstandardized } \\
\text { coefficients }\end{array}$ & & \multicolumn{1}{c|}{$\begin{array}{c}\text { Standardized } \\
\text { coefficients }\end{array}$} & & \\
\hline \multirow{4}{*}{1} & Model & $\mathrm{B}$ & Std. error & Beta & $\mathrm{t}$ & $\mathrm{Sig}$ \\
& & & & & 2.171 & .031 \\
& (Constant) & .632 & .291 & .622 & 10.923 & .000 \\
\hline
\end{tabular}

Source: Authors.

The Coefficient of the test indicate that the t values associated with Relationship Management is significant at the same level of F statistics. So, the regression eq will form the following shape:

$\mathrm{ME}=\quad 0.632+0.821(\mathrm{EI})$ 
Hence, we accept the $\mathbf{H}_{5}$ : Emotional Intelligence is considered as a scale ofManagerial Effectiveness

\section{CONCLUSION}

"Emotional Intelligence" is one of the emerging topic among the researchers and practitioners of Human Resource Management. It shows much promise in the organizational domain and is worthy of further investigation (Rosete \& Ciarrochi, 2005). The direction of ongoing researches for Emotional Intelligence was found towards the personal traits of any individual or leader such as emotionally intelligent leadership on talent retention, discretionary effort and employment brand (Palmer \& Gignac, 2012). Since the focus of this research was to see the impact of 4 Emotional Intelligence domains by Goleman (1997) on the Managerial Effectiveness scale by Gupta (1996) and to generalize the results to include either the Emotional Intelligence collectively or any of the 4 domains in 16 Managerial Effectiveness scale.

\subsection{Finding and discussion}

The response rate of this research remained to $53.5 \%$ from our respondents which were achieved with full personal efforts due to the busy routine of our respondents. Since all the respondents were ranked to some managerial position therefore, were constantly followed-up for the response. Nearly 4,00 questionnaires were randomly distributed through email and in person among the managers of different levels of Banks and Mobile Service companies in the area of Rawalpindi, Islamabad, Lahore \& Karachi. From the data of 191 managers we have concluded that all four domains of Emotional Intelligence namely Self-Awareness, Self-Management, Social-Awareness and Relationship Management have been found significant and also the collective impact as Emotional Intelligence, therefore suggested to include the trait of EI in the scale of Managerial Effectiveness developed by Gupta (1996).

The findings also suggests that the Managers higher on Emotional Intelligence likely to achieve business outcomes through their people. Regression analysis revealed that four domains of Emotional Intelligence independently and collectively have impact on the Managerial Effectiveness. These results may have important implications of Emotional Intelligence domains on Managerial Effectiveness for the inclusion in the scale however, caution must be given in making to wide a generalization of these findings, as the response rate is small at $5^{3.5} \%$.

Practically, a manager is always seems to be engaged with the variety of jobs at a same time and the most difficult is to handle annoyed and unsatisfied staff and customer. In such situation the traits and competencies such as emotional self-awareness, accurate self-assessment, self-confidence, Transparency, Adaptability, Opti- 
mism, Empathy, Pay attention to the details of own relationships etc are very much influenced and needed for the effective management (Singh, 2013).

\subsection{Limitations and future research directions}

The research had some limitations that will need to be addressed in future research. It will be interesting to evaluate the link between EI and Managerial Effectiveness in larger samples, and across different industries. The research was focused on the service industry and should must be replicated in other diverse market environments such as manufacturing concern and overtime to increase the generalizability of the theory.

Secondly, it was observed that questionnaire was not very well understood by the respondents, as it was adopted from previously held researches conducted in different environments. Therefore, it is suggested that rephrasing of the questionnaire is required to retest the model again in the local environment.

Thirdly, the moderately skewed research results indicated that the tendency of the respondents were remained to some one side and when investigated it was found that most of the respondents in this research were from back office operations who have less interaction directly with customers. It is recommended that future research may be conducted with more of the frontline managers who have more versatile interaction with other people. A special emphasis can be further addressed to the categories of sector vise employees i.e. public and private sector.

Lastly, time and cost are a limitation for any research. 


\section{REFERENCES}

Balaraman, S., Are Leadership Styles Predictive of Managerial Effectiveness. Indian Journal of Industrial Relations, 24(4), (1989): $399-415$

Bamel, Umesh K, Rangnekar, Santosh, \& Rastogi, Renu., Managerial Effectiveness in Indian Organisations: Reexamining an Instrument in an Indian Context. Research and Practice in Human Resource Management, 19(1), (2011): 69-78

Barling, J, Slater, F, \& Kelloway, E K., Transformational leadership and emotional intelligence: an exploratory study. Leadership \& Organization Development Journal, 21 (3), (2000): 157 - 161

Cherniss, Cary. (2000). Emotional Intelligence: What it is and Why it Matters. Paper presented at the Consortium for Research on Emotional Intelligence in Organizations, New Orleans, LA.

Covey, Stephen R. (1989). The 7 Habits of Highly Effective People: Franklin Covey Co.

Das, G.S., Conflict Management Styles of Efficient Branch Managers : As Perceived by Others. ASCI Journal of Management, $17(1),(1987): 30-38$

G. Cherniss, \& Adlet, M. (2000). Promoting Emotional Intelligence in Organizations: Making Training in Emotional Intelligence Effective. Alexandria, VA: ASTD Press.

Gardner, L, \& Stough, C., Examining the relationship between leadership and emotional intelligence in senior level managers. Leadership \& Organization Development Journal, 23(2), (2002): 68 - $7^{8}$

Ghiabi, Bibinaz, \& Besharat, Mohammad Ali. (2011). An investigation of the relationship between Personality dimensions and emotional intelligence. Procedia - Social and Behavioral Sciences, 3o(o), 416420. doi: $10.1016 /$ j.sbspro.2011.10.082

Goleman, Deniel. (1995). Emotional Intelligence. New York, NY: Bantam.

Gupta, Seeta., Managerial Effectiveness: Conceptual Framework and Scale Development. Indian Journal of Industrial Relations, 31 (3), (1996): 392-4,09

Jordan, \& Troth., Emotional intelligence and leader member exchange: The relationship with employee turnover intentions and job satisfaction. Leadership \& Organization Development Journal, 32 (3), (2011): 260 $-280$

Jawad, M. \& Naz, M. (2018). Pre and Post effect of Brexit polling on United Kingdom economy: an econometrics analysis of transactional change. Quality \& Quantity, 1-21. https://doi.org/10.1007/s11135018-0746-1

Mandell, B., \& Pherwani, S., Relationship between emotional intelligence and transformational leadership style: a gender comparison. Journal of Business and Psychology, ${ }_{7}$ (3), (2003): 387 - 4.04

Mayer, \& Salovey. (1997). What is Emotional Intelligence? In P. Salovey \& D.J. Sluyter (Eds.), Emotional Development and Emotional Intelligence: New York: Basic Books.

Mayer, J. D, Salovey, P., \& Caruso, D. R., Models of emotional intelligence. In R.J. Sternberg (Ed.), Handbook of Human Intelligence. New York, NY: Cambridge University Press, (2000): 396-420

Mayer, John D., Salovey, Peter, \& Caruso, David R., Emotional Intelligence: Theory, Findings, and Implications. Psychological Inquiry, 15(3), (2004): 197-215

Mintzberg, H. (1973). The Nature of Managerial Work. Harper and Row. 
Misumi, J., \& Peterson, M.F., The Performance Maintenance (PM) Theory Of Leadership : Review of a Japanese Research Program. Administrative Science Quarterly, 3o, (1985): 198 - 223

Misumi, Jyuji., Research On Leadership and Group Decision in Japanese Organisations. Applied Psychology: An International Review, 38, (1989): 321 - 336

Morse, John J., \& Wagner, Francis R., Measuring the Process of Manaerial Effectiveness. Academy of Manaement Journal, 21(1), (1978): $23-35$

Nwokah, Gladson., \& Ahiauzu, Augustine I., Emotional intelligence and marketing effectiveness. Marketing Intelligence \& Planning, 27(7), (2009): 864 - 881

Page, Carole, Wilson, Marie, \& Meyer, Denny. (1999). A Three Domain, Two Dimension Model of Managerial Effectiveness. Paper presented at the Academy of Business and Administrative Science Conference, Barcelona, Spain.

Palmer, Benjamin R., \& Gignac, Gilles. (2012). The impact of emotionally intelligent leadership on talent retention, discretionary effort and employment brand.

Industrial and Commercial Training, 44(1), 9-18.

Prati, L Melita, Douglas, Ceasar, Ferris, Gerald R, Ammeter, Anthony P, \& Buckley, M Ronald.,Emotional Intelligence, Leadership Effectiveness, and Team Outcomes. The International Journal of Organizational Analysis, $11(1),(2003): 21-40$

Rohr, Betty Anne. (May 2005). EMOTIONAL INTELLIGENCE: CORRELATES WITH EXERCISE ATTITUDES. Degree of Master of Education, University of Saskatchewan.

Rosete, David, \& Ciarrochi, Joseph., Emotional intelligence and its relationship to workplace performance outcomes of leadership effectiveness. Leadership \& Organization Development Journal, 26(5), $(2005): 388-399$

Sekaran, Uma, \& Bougie, Roger. (1984). Research Methods for Business (5th ed.): Student Book Company, New Delhi, India.

Singh, Prakash., Symbiotic Relationship Between Emotional Intelligence And Collegial Leadership. International Business \& Economics Research, 12(3), (2013): 331-344

Sivanathan, N., \& Fekken, G.C., Emotional intelligence, moral reasoning and transformational leadership. Leadership \& Organization Development Journal, 23(3/4), (2002): 198-205

Sy, Thomas, Tram, Susanna, \& O'Hara, Linda A. (2006). Relation of employee and manager emotional intelligence to job satisfaction and performance. Journal of Vocational Behavior, 68(3), 461-473. doi: 10.1016/j.jvb.2005.10.003

Thorndike, E. L. , Intelligence and its uses. Harper's Magazine, 140, (1920): 227-235

Thorndike, E. L., \& Stein, S., An evaluation of the attempts to measure social intelligence. Psychological Bulletin, 34, (1937): 275-284

Yang, Jixia, Zhang, Zhi-Xue, \& Tsui, Anne S. (2010). Middle Manager Leadership and Frontline Employee Performance: Bypass, Cascading, and Moderating Effects. Journal of Management Studies, 47 (4), 654-678. doi: $10.1111 / j .1467-6486.2009 .00902 \cdot x$ 
